\title{
ANALISIS RESPONS NETIZEN TERHADAP BERITA POLITIK DI MEDIA ONLINE
}

\author{
M. Khairul Anam \\ Magister Informatika \\ Universitas Islam Indonesia \\ Jl. Kaliurang Km.14,5 Sleman, Daerah Istimewa Yogyakarta \\ khairula210@gmail.com
}

\begin{abstract}
ABSTRAK
Partisipasi politik yang dilakukan oleh netizen di Indonesia saat ini sudah berkembang. Dengan adanya media online yang menyediakan berita politik, netizen bisa mengeluarkan pendapatnya dengan memberikan komentar terhadap berita politik yang disajikan oleh portal web berita. Dalam memberikan komentar, ada beberapa netizen yang berkomentar negatif maupun positif bahkan beberapa dari mereka berkomentar tidak relevan dengan berita yang disajikan. Penelitian ini menganalisis respon netizen terhadap berita politik yang disediakan media online seperti portal web berita. Analisa yang dilakukan menggunakan frame analysis (analisis bingkai), dengan menggunakan analisis ini komentar-komentar netizen dimasukan sesuai dengan frame yang telah ditentukan. Ada sembilan frame yang ditentukan dalam penelitian ini, yaitu dukungan, saran, metafora, perbandingan, tantangan, tidak relevan, sindiran, harapan, dan SARA.
\end{abstract}

Kata Kunci: Partisipasi Politik, Netizen, Bingkai Analisis, Berita Politik

\section{ABSTRACT}

Political participation which is conducted by netizens in Indonesia today is already highly developed. With the online media that provides political news, netizen could issue its opinion by commenting on political news that is presented by news web portal. In their comments, there are some netizens who commented negatively or positively and some of them are not even relevant to the story presented. This study analyzed the response of netizens to political news that is provided by online media such as news portal web. Analysis performed is using the frame analysis, by using this analysis netizen comments inserted in accordance with a predetermined frame. There are nine frames were identified in this study, that are: support, advice, metaphors, comparisons, challenges, irrelevant, satire, expectations, and racist.

Keyword: political participation, Netizen, Frame Analysis, politcal news 


\section{PENDAHULUAN}

Menurut hasil survei Asosiasi Penyelenggara Jasa Internet Indonesia (APJII) [1] tahun 2016, pengguna internet di Indonesia mencapai $51,8 \%$ atau 132,7 juta dari total populasi penduduk Indonesia 256,2 juta orang. Dengan semakin berkembangnya teknologi khususnya pada internet, tentu banyak orang yang menggunakannya dengan baik dan ada juga yang menggunakan internet untuk hal-hal yang tidak baik.

Pengguna internet melakukan aktivitas pada sebuah media online seperti media sosial dan portal web berita. Salah satu dampak positif penggunaan dari Internet ialah penggunaan media sosial untuk berinteraksi antara pemimpin dengan warganya. Dampak negatif dari penggunaan internet salah satunya adalah terlalu banyaknya informasi yang kurang valid. Sehingga mengakibatkan informasi yang bias di masyarakat. Pemanfaatan Internet yang salah seperti black campaign dimana internet dijadikan media untuk menyerang lawan dalam konteks Pemilihan Kepala Daerah (PILKADA), Pemilihan Legislatif (PILEG), bahkan Pemilihan Presiden (PILPRES).

Beberapa portal web berita yang menyediakan berita-berita terhangat dan terkini di Indonesia. Portal web berita juga menyediakan fitur untuk masyarakat online (netizen) memberikan komentar mereka terkait dengan berita yang sedang dibahas. Pada portal web berita tidak sedikit netizen untuk memberikan komentar terkait dengan berita yang disediakan. Berita yang disediakan oleh portal web berita, salah satunya adalah berita yang terkait dengan politik. Netizen biasanya memberikan komentar melalui media sosial ataupun langsung login sebagai pengguna aktif di portal web berita.

Peneliti yang melakukan penelitian pada politik online ini, seperti yang dilakukan [2] dalam penelitiannya menyebutkan bahwa politik online merupakan serangkaian kegiatan yang dilakukan secara online seperti melakukan pengiriman email pemerintahan resmi, memberikan kontribusi politik melalui media online, melakukan komunikasi dengan partai politik melaui email, telepon, sms ataupun menggunakan media sosial. Dari penjelasan tersebut maka dapat diambil kesimpulan bahwa, politik online merupakan kegiatan partisipasi politik yang dilakukan oleh netizen untuk melakukan aktivitas politik secara online. Aktivitas yang dimaksud disini adalah seperti memberikan opini mereka terhadap berita politik pada portal web berita ataupun berinteraksi kepada sesama netizen untuk membahas mengenai berita politik.

Peneliti-peneliti sebelumnya telah memaparkan manfaat dari penggunaan politik online. Salah satunya adalah penelitian yang dilakukan oleh [3] dalam penelitiannya memaparkan bahwa netizen memiliki peluang baru dalam berpartisipasi politik dan berkomunikasi dengan bergabung dalam grup politik, berinteraksi dengan institusi pemerintahan secara online, serta bertukar pendapat dan mendiskusikan informasi netizen lain. Manfaat lain dari politik online adalah memberi kesempatan kepada netizen untuk bisa saling memberikan pendapatnya pada berita online yang disediakan oleh portal web berita dan saling beriteraksi sesama netizen lain untuk membahas berita terkait dengan topik yang disajikan.

Politik Online di Indonesia saat ini sudah berkembang sangat pesat, netizen sudah mulai kritis dengan adanya berita politik di portal web berita. Banyak berita yang menjadi sorotan saat ini, salah satunya adalah berita yang terkait dengan pemerintahan Presiden dan Wakil Presiden Joko Widodo dan Jusuf Kalla (Jokowi-JK) yang di muat portal berita detik.com. Ada sebagian masyarakat yang puas dan ada juga masyarakat yang tidak puas dengan pemerintahan Jokowi-JK. Sebenarnya hal itu lumrah terjadi di kepemimpinan siapapun, tetapi dengan adanya Internet menjadikan hal tersebut lebih di expose oleh media. Hal ini bisa dilihat dari komentar-komentar pada berita yang berkaitan dengan pemerintahan Jokowi-JK.

Penelitian ini menganalisis komentar netizen dalam memberikan tanggapan terhadap sebuah berita politik di media online. Tujuannya adalah untuk mengetahui kedewasaan netizen dalam berpartisipasi politik dengan cara memberikan komentar terhadap berita politik di media online. Dari penjelasan telah diuraikan diatas, maka rumusan masalah dalam penelitain ini adalah bagaimana menganalisis prilaku netizen dalam merespon berita politik di media online.

\section{LANDASAN TEORI}

\subsection{Media Online}

Media online merupakan tempat di mana kita bisa mendapatkan informasi, salah satunya adalah berita. Berikut adalah peneliti yang melakukan penelitian terkait dengan media online yang dilakukan oleh [4], salah satu cara umum untuk mendapatkan informasi politik di internet dengan diskusi online, sebagian besar sumber utama berita seperti CNN, Fox News, dan The New York Times memiliki website, dan website ini berfungsi sebagai sumber berita utama secara online. Mereka juga menyediakan pesan dan opsi diskusi di website mereka, dimana viewer dapat memposting komentar dan bertukar pikiran.

Di Indonesia sendiri konsumsi berita secara online saat ini mulai dinikmati oleh netizen secara luas. Netizen Indonesia biasanya mengakses berita pada portal-portal web yang menyediakan banyak berita, beberapa diantaranya adalah detik.com, kompas, com, tempo.com, dan lain sebagainya. Portal web berita saat ini menyediakan banyak fitur pilihan berita sehingga netizen dapat memilih berita untuk mereka baca. Selain itu netizen juga dapat memberikan opini terhadap berita yang mereka baca pada kolom komenter. 


\subsection{Berita Politik di Media Online}

Saat ini media online salah satunya portal web berita, menyediakan berita-berita terupdate dan terkini untuk menarik perhatian netizen. Portal web berita seperti detik.com, viva.co.id, liputan6.com dan lain sebagainya, merupakan bagian portal web berita terpopuler saat ini di Indonesia, hal ini dapat dilihat pada situs alexa.com. Sebagian besar dari portal web tersebut menyediakan berita khusus politik untuk memudahkan netizen dalam memilih berita-berita politik.

Beberapa peneliti melakukan penelitian mengenai berita politik di media online, untuk mengetahui keterlibatan warga negara dalam berpolitik. Penelitian yang dilakukan [3] menguji hubungan antara kepercayaan informasi interpersonal dan keterbukaan dengan kegiatan politik berbasis internet dan sikap. Peneliti menggunakan beberapa media untuk dijadikan uji coba, diantaranya adalah Newspapers, Television, Online news sites of Newspapers and/or TV, Discussion forums, Blogs, News aggregators (such as Yahoo news), Social networking sites, Websites of organizations that are affiliated with political parties/candidates.

Selanjutnya penelitian yang dilakukan oleh [5], menggunakan sebuah platform Politnetz.ch, Politnetz.ch adalah sebuah platform online yang dapat meningkatkan komunikasi antara politisi dan pemilih di swiss. Pada Profil di politnetz.ch yang terdaftar baik itu sebagai pemilih atau politisi, dimana profil politisi memiliki bagian tambahan yang disebut "informasi politik". Bagian ini mencakup kepemilikan partai politik, yang dipilih antara pihak yang berlaku di Swiss. Pendaftaran sebagai politisi di politnetz.ch tidak diverifikasi oleh platform, karena fakta bahwa politisi tidak termotifasi untuk mempresentasikan dirinya sendiri. Hal ini menjadi jelas dalam informasi profil mereka : dua pertiga dari profil politisi include dengan link ke homepage mereka, sementara tidak ada profil pemilih yang memiliki link ke situs eksternal.

Penelitiannya lainnya yang dilakukan oleh [6], yang melakukan penelitian terhadap dua media online yaitu Dagbladet.no and Aftenposten.no. Penelitian ini menganalisis berita-berita yang ada pada kedua media online tersebut menggunakan frame analysis. Ada enam frame didapat dari kedua media online tersebut, diantaranya adalah metaphor, satire/irony, Justice, pressure, deliberation, and personal account.

\subsection{Pengaruh Politik Online di Masyarakat}

Dalam studi yang dilakukan [7], menggambarkan serangkaian teknik dan analisis yang menunjukkan lanskap pergeseran terhadap asimetri partisan dalam keterlibatan politik online. Temuan bahwa, berbeda dengan apa yang mungkin diharapkan mengingat dinamika politik secara online apalagi saat kampanye, yang condong ke pengguna twitter menunjukkan tingkat yang lebih besar dari kegiatan politik, ikatan sosial ketat, dan topologi jaringan komunikasi yang memfasilitasi penyebaran cepat dan luas informasi politik.

Penelitian [8], melihat dalam beberapa tahun terakhir, layanan eParticipation telah menjamur di pemerintah daerah, yang mempengaruhi pada komunikasi antara pemerintah, politisi dan warga negara. Sebagai masyarakat menjadi semakin digital, pemerintah sedang berusaha untuk meningkatkan kepentingan demokrasi melalui berbagai layanan eParticipation. Secara umum, eParticipation termasuk interaksi teknologi-dimediasi antara masyarakat sipil, politisi dan administrasi.

Layanan eParticipation tentu inisiatif kolektif dan melibatkan politik pengambilan keputusan. Namun, jelas bahwa peran walikota sangat berpengaruh, mengingat, terutama di awal, beberapa pemangku kepentingan secara implisit menunjukkan keengganan untuk mengambil bagian dalam pelayanan. Di sini, dapat mempertimbangkan bahwa walikota bertindak sebagai pengusaha institusional, yang diarahkan dan memimpin perubahan organisasi dalam melaksanakan pelayanan.

\subsection{Politik Online di Indonesia}

Penelitian yang dilakukan oleh [9] menjelaskan bahwa internet telah meningkatkan jumlah dan ketersediaan konten politik, sehingga mempengaruhi perdebatan mengenai kualitas wacana secara online yang baru muncul. Meskipun kondisi ini mungkin tampak secara teoritis ideal untuk memberikan pandangan baru terhadap diskusi politik. Di Indonesia, netizen sebagai pengamat politik online sudah memanfaatkan internet dan portal berita online sebagai media untuk memberikan saran dan memberikan kritik terhadap isu-isu politik. Hal ini diperlihatkan oleh sejumlah komentar atas berita politik yang terdapat di portal web berita seperti pada detik.com, viva.co.id, tribunenews.com, kompas.com, liputan6.com.

Penelitian yang senada juga telah dilakukan oleh [8] dalam jurnalnya yang berjudul Understanding eParticipation services in indonesian local government, tentang Layanan eParticipation di kota Yogyakarta. Pada saat itu, walikota dimaksudkan untuk meningkatkan pelayanan publik dengan menyediakan hotline layanan yang memungkinkan masyarakat untuk mengirim pesan langsung ke pemerintah daerah, oleh panggilan telepon atau pesan SMS. Yogyakarta berkolaborasi dengan perusahaan telekomunikasi nasional untuk memudahkan mengingat nomor khusus (2740) untuk menerima pesan SMS. Pesan masuk ditabulasi dan menanggapi secara manual. Layanan ini di bawah tanggung jawab Unit Satu-atap Layanan (Unit Pelayanan Terpadu Satu Atap [UPTSA]) yang pada tahun 2006 menjadi Departemen Lisensi (Dinas Perizinan).

Dari penjelasan-penjelasan sebelumnya maka penelitian ini berfokus pada media online di Indonesia berupa portal web berita. Portal web berita seperti detik.com, tribunnews.com, viva.co.id, dan lain sebagainya. Kemudian penelitian ini 
menganalisis komentar-komentar yang terdapat pada berita politik. Hal ini dilakukan untuk mengetahui bagaimana netizen memberikan tanggapannya pada sebuah berita politik.

\subsection{Teori Frame Analisis (Analisis Bingkai)}

Frame analysis (analisis bingkai) banyak digunakan oleh peneliti-peneliti terdahulu untuk melakukan analisis terhadap berita baik itu secara online maupun secara tradisional. Analisis bingkai pertama kali dilontarkan oleh Beterson pada tahun 1955. Penelitian [10], berpendapat bahwa mulanya, frame (bingkai) dimaknai sebagai struktur konseptual atau perangkat kepercayaan yang mengorganisir pandangan politik, kebijakan, dan wacana, serta yang menyediakan kategori-kategori standar untuk mengapresiasi realitas. Kemudian konsep ini dikembangkan lebih jauh oleh Goffman [11], yang mengandaikan bingkai sebagai kepingankepingan prilaku (strips of behavior) yang membimbing individu dalam membaca realitas.

Ada beberapa cara dalam melakukan proses pembingkaian yang dilakukan oleh peneliti sebelumnya, di bawah ini merupakan teknik pembingkaian yang dilakukan oleh Fairhurst and Sarr (1996) dalam [12], beliau melakukan pembingkaian dengan cara membagi ke dalam beberapa bingkai, yaitu:

- Metaphor: Untuk membingkai ide konseptual dibandingkan dengan sesuatu yang lain.

- Stories (myths, legends): Untuk membingkai topik melalui narasi dengan cara hidup dan mengesankan.

- Tradition (rituals, ceremonies): adat-istiadat budaya yang mengilhami penting dalam duniawi, terkait erat dengan artefak.

- Slogan, jargon, catchphrase: Untuk membingkai sebuah objek dengan frase menarik untuk membuatnya lebih berkesan dan berhubunganmampu.

- Artifact: Objek dengan nilai simbolis intrinsik

- fenomena visual / budaya yang memegang arti lebih dari objek itu sendiri.

- Contrast: Untuk menggambarkan obyek termasuk yang dibahas atau tidak.

- Spin: untuk menyajikan konsep dalam cara seperti untuk menyampaikan pertimbangan nilai (positif atau negatif) yang mungkin tidak segera jelas; untuk membuat bias yang melekat dengan definisi.

Kemudian penelitian yang dilakukan oleh [6], peneliti menemukan beberapa bingkai dalam penelitiannya, yaitu:

- metafora (metaphor) bingkai ini merupakan artikel yang menggunakan fairy tele figure untuk membahas isu-isu saat ini. Metafora pada artikel mereka digunakan untuk menunjukkan sesuatu yang salah dengan masyarakat norwegia saat ini.

- sindiran (satire/irony) penulis menemukan tiga artikel yang menggunakan satire untuk membingkai sebuah pesan. mereka melakukan ini untuk menjatuhkan lawan debat mereka.

- keadilan (Justice) bingkai ini menggunakan argumen yang berkaitan dengan keadilan, keadilan dan perlakuan yang sama untuk membingkai pesan.

- tekanan (pressure) bingkai ini berfokus pada tekanan psikologis yang dihadapi dalam masyarakat modern, dan berpendapat bahwa perlu mencari cara mengurangi tekanan.

- pertimbangan (Deliberation) Bingkai ini menyajikan argumen yang didukung oleh penalaran dan referensi pada literatur. Tujuannya adalah untuk meyakinkan pembaca melalui penayajian fakta dan argumen rasional.

- personal account, Bingkai dimana penulis membahas tema berdasarkan pengalamanpengalaman pribadinya.

\section{METODOLOGI}

Dibawah ini merupakan alur metodologi yang digunakan pada penelitian ini:

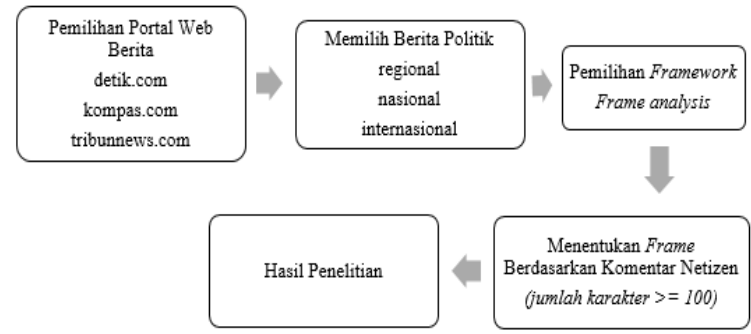

Gambar 1. Alur Metodologi Penelitian

Gambar 1 menunjukan penelitian ini menggunakan lima tahapan metodologi penelitian, berikut adalah penjelasan dari alur metodologi penelitian

\subsection{Pemilihan Portal Web Berita}

Penelitian ini nantinya akan merujuk ke portal web berita yang terpopuler di Indonesia. Pada situs [13], yang diakses pada 3 September 2016. Berikut adalah urutan situs terpopuler di Indonesia:

Tabel 1. Daftar portal web berdasarkan peringkat terpopuler

\begin{tabular}{c|c}
\hline Portal Web & Peringkat \\
\hline Google.co.id & Peringkat 1 \\
\hline Google.com & Peringkat 2 \\
\hline Youtube.com & Peringkat 3 \\
\hline Facebook.com & Peringkat 4 \\
\hline Blogspot.co.id & Peringkat 5 \\
\hline Yahoo.com & Peringkat 6 \\
\hline Tribunnews.com & Peringkat 7 \\
\hline Detik.com & Peringkat 8 \\
\hline Tokopedia.com & Peringkat 9 \\
\hline Bukalapak.com & Peringkat 10 \\
\hline Kompas.com & Peringkat 11 \\
\hline Kaskus.co.id & Peringkat 12
\end{tabular}




\subsection{Memilih Berita Politik}

Pemilihan berita ini, dilakukan dengan mengamati setiap berita politik yang ada pada ketiga portal yang telah ditentukan. Pada berita dipilih berdasarkan berita yang masih hangat dibicarakan. Pemilihan berita tersebut diambil dari mulai bulan juli sampai dengan bulan september tahun 2016. Penelitian mengambil tiga berita dari masing-masing portal web berita, yatu dari regional, nasional, dan internasional. Hal ini dilakukan untuk mengetahui berita-berita mana yang banyak dikomentari oleh netizen.

\subsection{Pemilihan Framework}

Penelitian ini menggunakan analisis bingkai untuk menganalisis komentar yang ada pada beritaberita politik karena bingkai ini bisa mengkategorikan komentar berdasarkan bingkaibingkai yang telah ditentukan. Sehingga memudahkan dalam menganalisa komentarkomentar dari netizen terhadap berita politik.

Analisis bingkai yang digunakan adalah analisis bingkai Individual, karena penelitian ini menganalisis setiap komentar yang ada pada setiap berita politik yang dijadikan obyek penelitian. Bingkai-bingkai pada penelitian ini mengambil beberapa bingkai yang terdapat pada penelitian terdahulu dan menambahkan bingkai baru. Bingkai baru didapatkan setelah dilakukan analisis ada beberapa komentar yang tidak cocok dengan bingkai pada penelitian terdahulu sehingga harus ditambahkan beberapa bingkai yang baru.

\subsection{Menentukan bingkai berdasarkan komentar netizen}

Komentar yang dianalisis pada penelitian ini hanya komentar yang berjumlah 100 karakter atau lebih, karena komentar yang tidak melebihi dari 100 karakter banyak yang tidak relevan dengan topik berita yang sedang dibahas dan komentarkomentarnya pun terkadang cenderung menggunakan kata-kata kasar. Setelah menentukan komentar, barulah komentar-komentar tersebut dianalisis menggunakan analisis bingkai (Frame Analysis).

\subsection{Hasil Penelitian}

Hasil penelitian ini berupa bingkai-bingkai yang telah ditentukan berdasarkan komentar-komentar pada berita politik yang dijadikan obyek.

\section{HASIL PENELITIAN}

Penelitian ini lebih berfokus pada partisipasi netizen terhadap berita-berita politik di tiga portal web berita yang telah ditentukan. Bentuk dari partisipasi netizen berupa komentar yang diberikan pada berita politik di media online. Kemudian berita-berita tersebut dipilih berdasarkan panjang karakter yang telah ditentukan. Kemudian komentarkomentar tersebut dianalisis menggunakan analisis bingkai. Pada tabel 2 merupakan komentar utama

Tabel 2. Jumlah komentar utama

\begin{tabular}{|l|l|l|l|}
\hline Portal Web & Jenis Berita & Judul Berita & $\begin{array}{l}\text { Jumlah } \\
\text { Komentar }\end{array}$ \\
\hline Detik.com & Regional & $\begin{array}{l}\text { Jokowi Ingin Jakarta Jadi Ibu } \\
\text { Kota Megapolitan Maju, Ahok: } \\
\text { Siap Pak! }\end{array}$ & 44 \\
\cline { 2 - 4 } & Nasional & Apa yang Salah dengan Jokowi? & 206 \\
\cline { 2 - 4 } & Internasional & $\begin{array}{l}\text { Hadapi MEA, RI Perlu } \\
\text { Tingkatkan Kompetensi SDM } \\
\text { dengan Pendididkan Berkualitas }\end{array}$ & 11 \\
\hline Tribunnews.com & Regional & $\begin{array}{l}\text { Ini 5 Penerawangan Mbah } \\
\text { Mijan Soal Peluang Agus } \\
\text { Yudhoyono di Pilkada Jakarta }\end{array}$ & 64 \\
\cline { 2 - 5 } & Nasional & $\begin{array}{l}\text { Pak Jokowi, Ngurus Negara } \\
\text { Jangan Disamakan dengan } \\
\text { Ngurus Usaha Mebel }\end{array}$ & 426 \\
\cline { 2 - 5 } & Internasional & $\begin{array}{l}\text { Singapura Dinilai Jegal } \\
\text { Indonesia Jika Keluarkan } \\
\text { Kebijakan Tahan Uang WNI }\end{array}$ & 7 \\
\hline Kompas.com & Regional & $\begin{array}{l}\text { Prasetio Edi Siap Jadi Ketua } \\
\text { Tim Pemenangan Ahok-Djarot } \\
\text { Gantikan Nusron Wahid }\end{array}$ & 24 \\
\cline { 2 - 5 } & Nasional & $\begin{array}{l}\text { Pemerintah Minta Majelis } \\
\text { Hakim MK Tolak Gugatan } \\
\text { Ahok }\end{array}$ & 33 \\
\cline { 2 - 5 } & Internasional & $\begin{array}{l}\text { Jokowi Minta Negara G-20 } \\
\text { Contoh Indonesia dalam } \\
\text { Membrantas Korupsi }\end{array}$ & 23 \\
\hline Total & \multicolumn{3}{|l|}{838} \\
\hline
\end{tabular}


Dari data Tabel 2, selanjutnya yaitu pemilihan komentar yang berjumlah 100 karakter atau lebih, Tabel 3 merupakan data yang akan dianalisis.

Tabel 3. Jumlah komentar yang dianalisis

\begin{tabular}{|c|c|c|c|}
\hline Portal Web & Jenis berita & $\begin{array}{l}\text { Komentar } \\
\text { dianalisis }\end{array}$ & $\begin{array}{l}\text { Jumlah } \\
\text { Komentar }\end{array}$ \\
\hline \multirow[t]{3}{*}{ Detik.com } & Regional & 15 & \multirow[t]{3}{*}{137} \\
\hline & Nasional & 116 & \\
\hline & Internasional & 6 & \\
\hline \multirow[t]{3}{*}{ Tribunnews.com } & Regional & 22 & \multirow[t]{3}{*}{157} \\
\hline & Nasional & 129 & \\
\hline & Internasional & 6 & \\
\hline \multirow[t]{3}{*}{ Kompas.com } & Regional & 8 & \multirow[t]{3}{*}{44} \\
\hline & Nasional & 25 & \\
\hline & Internasional & 11 & \\
\hline \multicolumn{3}{|l|}{ Total } & 338 \\
\hline
\end{tabular}

\subsection{Penentuan Bingkai}

Dalam proses analisis ada tahapan untuk menentukan bingkai pada penelitian ini. Tahap pertama yaitu menganalisa komentar-komentar untuk menentukan komentar tersebut masuk ke bingkai yang mana. Analisa tahap pertama menemukan 12 bingkai yang sesuai dengan

komentar-komentar yang terdapat pada berita politik. Berikut adalah bingkai yang didapatkan pada tahap pertama: Sependapat, mendukung, peringatan, saran, metafora, tidak peduli, perbandingan, tantangan, tidak relevan, sindiran, harapan, dan SARA (suku, agama, ras, dan antargolongan).

\subsection{Evaluasi Bingkai}

Kemudian pada tahap yang kedua melalukan evaluasi terhadap bingkai-bingkai yang telah didapatkan, hasilnya bingkai-bingkai tersebut di kurangi menjadi sembilan bingkai, karena beberapa bingkai bisa digabungkan dengan bingkai yang lainnya. Alasan lain mengapa bingkai digabungkan karena salah satu bingkai tidak banyak netizen yang berkomentar pada bingkai yang telah ditentukan.
Adapun bingkai yang digabungkan adalah sebagai berikut:

- Sependapat dan mendukung menjadi mendukung, karena komentar pada bingkai sependapat dan mendukung hampir sama yaitu sama-sama dalam mendukung aktor pada berita yang sedang dibahas.

- Tidak peduli dan tidak relevan menjadi tidak relevan, karena kedua bingkai ini sama-sama tidak menunjukkan adanya komentar yang mereka lakukan mengarah kepada topik yang disajikan.

- Peringatan dan tantangan menjadi tantangan, komentar pada bingkai peringatan dan tantangan ini sama-sama memberikan tantangan kepada aktor untuk menjadi yang aktor komentari pada berita yang sedang dibahas.

Selain itu kasus lain yang ditemukan adalah adanya dua bingkai pada satu komentar. Pada kasus seperti ini analisis yang dilakukan adalah mengamati komentar tersebut lebih berat kemana komentar tersebut untuk ditentukan bingkainya. Salah satu contoh komentar yang memiliki dua bingkai seperti berikut ini. "Skali lagi,siapapun yg mencalonkan dari pihak,Grinda jgn di pilih. Andai kata rakyat sampai memilih,berarti Rakyt itu sendiri siap2 jdi budaknya. Dan siap2 menderita,menyesal,nnti karena memperkaya pihaknya,bukan untuk rakyat,tapi untuk kepentingan golongan,anggap saja rakyat siap jdi jongosnya". Pada komentar tersebut terdapat dua bingkai yaitu metafora dan sindiran, tetapi komentar diatas lebih berat pada bingkai sindiran. Karena netizen menyindir pihak gerindra, jika memilih partai tersebut dampaknya akan membuat rakyat semakin menderita.

Setelah melalui tahapan diatas, pada lampiran 1 merupakan bingkai-bingkai yang akan digunakan pada penelitian ini. Kemudian setelah dilakukan analisis maka didapatkan jumlah masing-masing pada bingkai. Dibawah ini merupakan jumlah masing-masing pada bingkai.

Tabel 4. Jumlah masing-masing komentar pada bingkai

\begin{tabular}{|c|c|c|c|c|c|c|c|c|c|c|}
\hline Berita & Mendukung & Saran & Metafora & Perbandingan & Tantangan & $\begin{array}{c}\text { Tidak } \\
\text { relevan }\end{array}$ & Sindiran & Harapan & SARA & jumlah \\
\hline $\mathrm{Dr}$ & 3 & 5 & 0 & 0 & 0 & 0 & 5 & 2 & 0 & 15 \\
\hline $\mathrm{Dn}$ & 16 & 4 & 5 & 0 & 2 & 0 & 89 & 0 & 0 & 116 \\
\hline $\mathrm{Di}$ & 0 & 0 & 1 & 0 & 0 & 0 & 5 & 0 & 0 & 6 \\
\hline $\mathrm{Tr}$ & 1 & 0 & 1 & 0 & 2 & 2 & 10 & 2 & 4 & 22 \\
\hline $\mathrm{Tn}$ & 4 & 4 & 21 & 3 & 4 & 3 & 82 & 6 & 2 & 129 \\
\hline $\mathrm{Ti}$ & 0 & 0 & 0 & 1 & 0 & 0 & 5 & 0 & 0 & 6 \\
\hline $\mathrm{Kr}$ & 0 & 2 & 0 & 1 & 1 & 0 & 4 & 0 & 0 & 8 \\
\hline $\mathrm{Kn}$ & 0 & 2 & 1 & 0 & 1 & 0 & 21 & 0 & 0 & 25 \\
\hline $\mathrm{Ki}$ & 0 & 1 & 0 & 0 & 0 & 0 & 10 & 0 & 0 & 11 \\
\hline jumlah & 24 & 18 & 29 & 5 & 10 & 5 & 231 & 10 & 6 & 338 \\
\hline
\end{tabular}


Keterangan :

Dr: Berita detik.com Regional, Dn: Berita detik.com Nasional, Di: Berita detik.com Internasional, Tr: Berita tribunnews.com Regional, Tn: Berita tribunnews.com Nasional, Ti: Berita tribunnews.com Internasional, Kr: Berita kompas.com Regional, Kn: Berita kompas.com Nasional, dan Ki: Berita kompas.com Internasional.

\section{Kesimpulan dan saran}

\subsection{Kesimpulan}

Dari pembahasan dapat disimpulkan bahwa dengan adanya berita politik pada media online, dapat juga diketahui bagaimana netizen memberikan pendapatnya mengenai berita politik yang disajikan. Penelitian ini menggunakan analisis bingkai karena analisis ini mampu mengelompokkan beberapa kategori bingkai yang memudahkan dalam menganalisis dan memudahkan pembaca dalam mengetahui bagaimana cara netizen memberikan tanggapan pada berita politik di media online. Ada sembilan bingkai yang ditemukan, yaitu mendukung, saran, metafora, perbandingan, tantangan, tidak relevan, sindiran, harapan, dan SARA. Kesembilan bingkai didapatkan berdasarkan dari analisis yang telah dilakukan. Bingkai ini didapatkan dari beritaberita yang telah ditentukan untuk dijadikan obyek penelitian. Ada sembilan berita yang dianalisis, dari sembilan berita terdapat 838 komentar utama. Kemudian dari 838 komentar disaring, hanya komentar yang memiliki jumlah karakter 100 atau lebih yang dianalisis. Setelah di saring didapatkan 338 komentar yang dianalisis.

Setelah dilakukan analisis, didapatkan beberapa temuan, dari berita yang dianalisis sudah jarang netizen yang berkomentar mengadung unsur SARA dan komentar yang tidak relevan dengan topik yang sedang dibahas, namun netizen lebih suka berkomentar dengan cara menyindir aktor yang sedang dibahas dalam berita. Selanjutnya ada beberapa komentar yang terdapat pada dua bingkai atau lebih, maka harus dilihat bingkai mana yang lebih dominan. Inkonsistensi akan terjadi apabila suatu komentar ada pada dua bingkai atau lebih.

\subsection{Saran}

Berikut adalah beberapa saran untuk dilakukan penelitian selanjutnya

- Dilakukan pengolahan data dengan menggunakan program yang bisa mengolah data dengan data yang lebih banyak. Program tersebut diusahakan bisa langsung membuat secara otomatis komentar tersebut masuk ke dalam bingkai yang mana

- Melakukan perbandingan dengan menggunakan framework lain agar bisa mengetahui framework mana yang lebih baik dalam melakukan analisa terhadap komentar-komentar yang ada pada portal web berita.

\section{Daftar Pustaka}

[1] APJII, "Penetrasi \& Prilaku Pengguna Internet Indonesia," 2016.

[2] A. Smith, K. L. Schlozman, S. Verba, and H. Brady, "The Demographics of Online and Offline Political Participation," 2009. [Online]. Available: http://www.pewinternet.org/2009/09/01/thedemographics-of-online-and-offlinepolitical-participation/. [Accessed: 21-Jun2016].

[3] I. Himelboim, R. W. Lariscy, S. F. Tinkham, and K. D. Sweetser, "Social Media and Online Political Communication: The Role of Interpersonal Informational Trust and Openness," J. Broadcast. Electron. Media, vol. 56, no. 1, pp. 92-115, 2012.

[4] N. Jun, "Contribution of Internet news use to reducing the influence of selective online exposure on political diversity," Comput. Human Behav., vol. 28, no. 4, pp. 14501457, 2012.

[5] D. Garcia, A. Abisheva, S. Schweighofer, U. Serdult, and F. Schweitzer, "Network polarization in online politics participatory media," Submmited to Policy Internet, pp. 1-34, 2014.

[6] M. R. Johannessen, "Please Like and Share! A Frame Analysis of Opinion Articles in Online News," IFIP Int. Fed. Inf. Process. 2015, vol. 9249, pp. 15-26, 2015.

[7] M. D. Conover, B. Gonçalves, A. Flammini, and F. Menczer, "Partisan asymmetries in online political activity," EPJ Data Sci., vol. 1, no. 1, pp. 1-19, 2012.

[8] F. Wahid and $\varnothing$. Sæbø, "Understanding eParticipation services in indonesian local government," Lect. Notes Comput. Sci. (including Subser. Lect. Notes Artif. Intell. Lect. Notes Bioinformatics), vol. 8407 LNCS, pp. 328-337, 2014.

[9] M. E. Wojcieszak and D. C. Mutz, "Online groups and political discourse: Do online discussion spaces facilitate exposure to political disagreement?," J. Commun., vol. 59, no. 1, pp. 40-56, 2009.

[10] Alex Sobur, Analisis Teks Media Suatu Pengantar untuk Analisis Wacana, Analisis Semiotik, dan Analisis Framing. Bandung: PT Remaja Rosdakarya, 2004.

[11] G. Erving, "Frame Analysis: An Essay on the Organization of Experience." 1974.

[12] masscommtheory.com, "Mass Communication Theory: from Theory to Practical Application." [Online]. Available: https://masscommtheory.com/theoryoverviews/framing-theory/.

[13] alexa.com, "Top Sites in Indonesia," 2016. 


\section{LAMPIRAN}

Lampiran 1. Bingkai yang digunakan pada penelitian

\begin{tabular}{|c|c|c|c|}
\hline No & Bingkai & Definisi & Contoh \\
\hline 1 & Mendukung & $\begin{array}{l}\text { pada bingkai ini, netizen } \\
\text { bersifat mendukung atau } \\
\text { setuju dengan aktor yang } \\
\text { sedang dibahas pada topik. }\end{array}$ & $\begin{array}{c}\text { Periode pemerintahan sekarang adalah membangun } \\
\text { basis bernegara yg benar. Membenahi kerusakan total } \\
\text { perilaku pemimpin dan rakyat pada periode-periode } \\
\text { sebelumnya. Hasilnya? mustahil dapat terealisir dalam } \\
\text { 1-2 tahun.... tetapi akuntabilitas, kejujuran, dan visi } \\
\text { pemimpin pmerintahan saat ini sudah berjalan dgn } \\
\text { benar }\end{array}$ \\
\hline 2 & Saran & $\begin{array}{l}\text { bingkai ini } \\
\text { mengelompokkan } \\
\text { komentar-komentar dari } \\
\text { netizen yang memberikan } \\
\text { saran kepada aktor }\end{array}$ & $\begin{array}{c}\text { Konsep biaya transportasi seharusnya yg termahal } \\
\text { adalah kendaraan pribadi (pajak, parkir \& dan BBM } \\
\text { harus lebih tinggi dari kendaraan massal), urutan } \\
\text { kedua adlah taxi (mesti lebih murah drpada pakai } \\
\text { mobil pribadi, kalau perlu ada subsidi), urutan ke } 3 \\
\text { adalah motor atau ojek, ke empat kereta, kelima bus } \\
\text { (kalau perlu disubsidi habis) di jamin kemacetan akan } \\
\text { berkurang }\end{array}$ \\
\hline 3 & Metafora & $\begin{array}{c}\text { bingkai yang } \\
\text { menggunakan } \\
\text { pengandaian dalam } \\
\text { mengomentari aktor yang } \\
\text { sedang dibahas dalam } \\
\text { topik } \\
\end{array}$ & $\begin{array}{l}\text { anak buahnya jendral kuda belang mah oon...mantan } \\
\text { presiden tuh punya hak imunitas atas } \\
\text { keputusannya...kecuali boss mu itu.. diadili dan } \\
\text { dipecat mahkamah kehormatan trus kabur ke } \\
\text { jordania...ngaku jd pelatih militer disana....padahal jd } \\
\text { pelatih kuda...dasar jendral belang }\end{array}$ \\
\hline 4 & Perbandingan & $\begin{array}{l}\text { bingkai yang ada pada } \\
\text { komentar seperti } \\
\text { membanding-bandingkan } \\
\text { antara aktor satu dengan } \\
\text { aktor lainnya } \\
\end{array}$ & $\begin{array}{c}\text { Tapi pk. Jokowi lbh brhasil dari pda pemerintahan } \\
\text { sebelum nya. Dn mampu selesaikan berbagai } \\
\text { permasalahan bangsa. Dn mampu selesaikan proyek } \\
\text { yang mangkrak2 }\end{array}$ \\
\hline 5 & Tantangan & $\begin{array}{l}\text { bingkai yang } \\
\text { mengelompokkan netizen } \\
\text { yang komentarnya } \\
\text { memberikan tantangan } \\
\text { kepada aktor yang sedang } \\
\text { dibahas dalam topik } \\
\end{array}$ & $\begin{array}{l}\text { Presiden hanya menegaskan tentang hak diskresi. } \\
\text { Orang2 gerindra langsung nyamber bikinopini } \\
\text { murahan. Ga usah mempertontonkan kebodohan } \\
\text { hukum dan ketakutan dilabrak prabowo. Tanding lg } \\
\text { aja di2019. Lebih fer. }\end{array}$ \\
\hline 6 & $\begin{array}{l}\text { Tidak } \\
\text { Relevan }\end{array}$ & $\begin{array}{l}\text { komentar netizen yang } \\
\text { tidak sama sekali } \\
\text { mengomentari topik yang } \\
\text { disajikan }\end{array}$ & $\begin{array}{c}\text { takut jangan dicoba...! berani bole coba...! itu baru laki, } \\
\text { ayoo...! gabung bersama kami di } \\
\text { jaminhoki(dot)com...hoki anda tidak ditentukan kapan } \\
\text { apalagi tidak anda coba...! }\end{array}$ \\
\hline 7 & Sindiran & $\begin{array}{l}\text { netizen yang } \\
\text { mengomentari aktor yang } \\
\text { sedang dibahas dalam } \\
\text { topik dan juga } \\
\text { mengomentari portal web } \\
\text { berita yang menyediakan } \\
\text { topik tersebut dengan cara } \\
\text { menyindir. }\end{array}$ & $\begin{array}{l}\text { Logic aja mana mungkin Gerindra mau mbangun negri } \\
\text { ini jika Jokowi berhasil membangun orang Gerindra } \\
\text { pasti sakit dan bagai mana caranya menjatuhkan } \\
\text { pemerantahan yang ada biar rakyat nggak percaya } \\
\text { sama Jokowi JK dan beralih ke Gerindra }\end{array}$ \\
\hline 8 & Harapan & $\begin{array}{l}\text { komentar netizen yang } \\
\text { berharap kepada aktor } \\
\text { yang sedang dibahas pada } \\
\text { topik. }\end{array}$ & $\begin{array}{c}\text { Saatnya yg muda berkarya, pmimpin harusnya laki" } \\
\text { muda lagi pasanganya prempuan cocok pas sdah, smga } \\
\text { jakarta lbih baik ditangan maz agus dan bu ini, smoga } \\
\text { menang }\end{array}$ \\
\hline 9 & SARA & $\begin{array}{l}\text { komentar yang berkaitan } \\
\text { dengan suku, agama, ras, } \\
\text { dan antargolongan. }\end{array}$ & $\begin{array}{l}\text { Ahok sebagai Representasi Bawah sadar Politik } \\
\text { Keinginan Cina Berkuasa di Indonesia }\end{array}$ \\
\hline
\end{tabular}

